УдК 339.923

K. Redko,

$\mathrm{PbD}$ in Economics, Senior Lecturer, Faculty of Management and Marketing,

International Economy Department, National Tecbnical University

of Ukraine "Igor Sikorsky Kyiv Polytechnic Institute"

ORCID ID: 0000-0003-2609-3471

M. Mabmood,

student of group YS-92mp, National Technical University

of Ukraine "Igor Sikorsky Kyiv Polytechnic Institute"

ORCID ID: 0000-0003-2765-7566

DOI: $10.32702 / 2306-6814.2020 .17-18.69$

\title{
UKRAINE AND KINGDOM OF SAUDI ARABIA: ESTABLISHING BILATERAL ONES ECONOMIC RELATIONS
}

\author{
К. Ю. Редько, \\ к. е. н., старший викладач, факультет менеджменту та маркетингу, кафедра міжнародної економіки, \\ Національний технічний університет України "Київський політехнічний інститут імені Ігоря Сікорського" \\ Міркхас Хамід Махмуд, \\ студент групи УС-92 мп, факультет менеджменту та маркетингу, кафедра міжнародної економіки, \\ Національний технічний університет України "Київський політехнічний інститут імені Ігоря Сікорського"
}

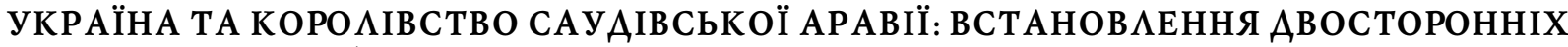
ЕКОНОМІЧНИХ ВІАНОСИН
\end{abstract}

The importance of the Persian Gulf region for Ukraine is due to the significant potential for mutually beneficial trade and economic cooperation. Despite the fact that Ukraine is one of the energydeficient countries, the possibilities of import or transit of energy from the Gulf states are quite limited. The priorities of Ukraine's policy in the region are the development of balanced, equal and mutually beneficial relations, strengthening Ukraine's economic position in the region's markets, maintaining security at the southern borders of our state, strengthening regional security and stability. Ukraine considers important cooperation in the field of exploration, development, arrangement and modernization of oil and gas fields, design and construction of oil and gas infrastructure, joint production of hydrocarbons in the two countries and attracting investment in the modernization of Ukraine's gas transportation system. The automobile industry can become a promising area of Saudi-Ukrainian cooperation. An important area is cooperation in space, in particular, in the joint production of artificial satellite systems. launch of Saudi satellites. The aim of the article is to analyze the size and relation of commercial and investment between Ukraine and $K S A$, through finding the figures of the main product or services that changed or procured by the two countries, with raining the main impact factors that effecting the trade on the country level, also witnessed cooperation in various fields, as in 2016 the Kingdom and Ukraine signed agreements, including the double taxation agreement, the investment protection agreement, and the economic and commercial framework agreement for commercial, economic, scientific and technical cooperation. The main exported commodities were plastics and their articles, machinery and machine tools and their parts, fertilizers, and various chemical products, in addition to ready-made clothes. While the main imported commodities in the same year were: cereals, iron and steel (steel), fats and animal or vegetable oils, made of iron or casting (steel), and meat, offal and edible parts. 
Важливість регіону Перської затоки для України зумовлена значним потенціалом взаємовигідного торговельно-економічного співробітництва. Попри те, що Україна є однією з енергодефіцитних країн, можливості імпорту або транзиту енергії з країн Перської затоки досить обмежені. Пріоритетами української політики в регіоні є розвиток збалансованих, рівноправних та взаємовигідних відносин, зміцнення економічних позицій України на ринках регіону, підтримка безпеки на південних кордонах нашої держави, зміцнення регіональної безпеки та стабільності. Україна розглядає важливу співпрацю угалузі розвідки, розробки, облаштування та модернізації нафтогазових родовищ, проектування та будівництва нафтогазової інфраструктури, спільного видобутку вуглеводнів у двох країнах та залучення інвестицій у модернізацію газотранспортної системи України. Автомобільна промисловість може стати перспективним напрямом саудівсько-українського співробітництва. Важливою сферою є співпраця у космосі, зокрема, у спільному виробництві штучних супутникових систем. Нами було проаналізовано розвиток комерційних та інвестиційних відносин між Україною та Саудівською Аравією. Досліджено основні товари та послуги обох держав. Проаналізовано співпрацю в різних сферах. Дослідили ми такожй угоди, які було підписано між державами у 2016 році, а саме: угоду про уникнення подвійного оподаткування, угоду про захист інвестицій та економічну угоду. Досліджено економічне, науково-технічне співробітництво. Визначено, що основними товарами, що експортуються з Саудівської Аравії, були, крім готового одягу, пластмаси та виробів з неї, машини та верстати та їх частини, добрива та різноманітна хімічна продукція. Тоді як основними імпортними товарами були: крупи, залізо та сталь (сталь), жири та тваринні або рослинні олії, виготовлені із заліза або виливків (сталь), м'ясо, субпродукти. Саудівсько-українська співпраця в галузі освіти вважаємо пріоритетом для обох країн. Україна має конкурентні переваги через те, що можемо запропонувати дешевші, але також якісні альтернативи західним товарам та послугам.

Key words: Ukraine, Kingdom of Saudi Arabia, economic cooperation, trade, investment.

Ключові слова: Україна, КороліВстъо Саудівська АраВія, економічне співробітничтъо, товарообіг, інВеcmuцiï.

\section{PROBLEM STATEMENT IN GENERAL} AND ITS CONNECTION WITH IMPORTANT SCIENTIFIC OR PRACTICAL TASKS

The rather capacious Russian market has closed for Ukrainian producers. Russian business has set a course for the substitution of Ukrainian products. Conversely, Ukrainian producers, such as military products or dual-use goods, are themselves forced to suspend bilateral cooperation. Moscow is trying to block the promotion of goods from Ukraine through its powerful lobby in the Central Asian republics. Quotas provided by the European Union and the United States do not fully correspond to Ukrainian production. Export operations of ten exclude the segment of science-intensive products. Cooperation with Chinese partners is complicated by the negative position of the White House. There is a struggle for African markets between the former metropolises, Russia as the successor to the former USSR, Turkey as the unofficial successor of the Ottoman Empire and the same China. In addition, African countries with their large mineral reserves need, as does Ukraine, foreign investment to develop and optimize the mining industry [12].

In other words, potential exporters are interested in countries that pursue an independent foreign policy, have a large population and significant financial resources for investment and at the same time problems with agricultural production and, ideally, are open to exports of metallurgical, chemical and engineering industries. If we take into account that ideal situations are extremely rare, then in other respects the Gulf countries, in particular the United Arab Emirates, can become quite promising partners for Ukraine.

\section{ANALYSIS OF RECENT RESEARCH AND PUBLICATIONS}

A significant contribution to the study works of A. Veselovsky became this region, O. Volovich, S. Gutsalo, O. Koppel, V. Nagaichuk, B. Parahonsky, R. Petyura, L. Skorokhod, Y. Skorokhoda, N. Yusef, V. Shveda and others. Among domestic studies that focus their focus on the economic aspects of the relationship Ukraine with the Gulf countries, including and with Saudi Arabia, should be singled out works by J. Igoshina, O. Volovich, V. Makukh.

\section{FORMULATION OF THE GOALS OF THE ARTICLE}

As a result of the significant deterioration of Ukrainian-Russian relations caused by the Kremlin's aggression, the domestic economy found itself in a rather difficult situation, when decades of established ties were severed almost in an instant. Chinese and Central Asian partners cannot yet replace lost markets. Hopes for the West's help have not yet been fully realized. The main idea of our article is to trace the development of Ukrainian- 
Table 1. Comparative analysis of Ukraine and Saudi Arabia

\begin{tabular}{|l|l|l|}
\hline \multicolumn{1}{|c|}{ The comparison } & \multicolumn{1}{|c|}{$\begin{array}{c}\text { Kingdom of } \\
\text { Saudia Arbia }\end{array}$} & \multicolumn{1}{|c|}{ Ukraine } \\
\hline The area space & $2,149,690 \mathrm{~km} 2$ & $603,550 \mathrm{~km} 2$ \\
\hline The population & $33,413,660$ & $42,418,235$ \\
\hline The population density & $15 \mathrm{Km} 2 / 205$ & $77 \mathrm{Km} 2 / 115$ \\
\hline The capital city & Riyad & Kiev \\
\hline The formal language & Arabic & Ukraine and Russian \\
\hline The Currency & Saudi Arabic Real & Ukrainian Hryvnia UAH \\
\hline $\begin{array}{l}\text { Gross Domestic Product } \\
\text { (Purchase Power } \\
\text { Product) billion dollars }\end{array}$ & $\begin{array}{l}1,775,143,975,121 \\
\text { Year 2017 }\end{array}$ & $\begin{array}{l}369,566,394,804 \\
\text { Year 2017 }\end{array}$ \\
\hline $\begin{array}{l}\text { The Gross Domestic } \\
\text { Product per person (in } \\
\text { USD) }\end{array}$ & 23,411 USD & $\begin{array}{l}3,621 \text { USD } \\
\text { Year 2018 } 2011\end{array}$ \\
\hline
\end{tabular}

Saudi foreign economic relations, as well as to investigate their significance, to single out strengths and vulnerabilities, suggest ways to expand and revitalize the relationship

\section{PRESENTATION OF THE MAIN RESEARCH MATERIAL}

The Kingdom of Saudi Arabia is considered one of the most important partners of Ukraine in the commercial and economic fields in the Arab Gulf region and the Middle East in general, and it ranks second among the Arab countries in terms of the volume of trade and service exchange.

At the stage of Ukraine's independence, interest in it was limited to a likely source of arms diversification, as investment in the Ukrainian economy was high due to economic transition and political instability. During 2008, there was a decline in bilateral trade. The low level of Ukrainian imports is explained by the fact that the main share of total CSR exports is oil and oil products, in which Ukraine has not shown interest. Metallurgical products traditionally provided a third of Ukraine's export earnings in trade with CSR. Ukraine considers important cooperation in the field of exploration, development, arrangement and modernization of oil and gas fields, design and construction of oil and gas infrastructure, joint production of hydrocarbons in the two countries and attracting investment in the modernization of Ukraine's gas transportation system. The automobile industry can become a promising area of Saudi-Ukrainian cooperation. The next step in entering the Saudi market was the signing of a distribution agreement between $\mathrm{HC}$ Avtokraz and the largest automobile company in Saudi Arabia - Abdullatif Alissa Automobile Co. An important area is cooperation in space, in particular, in the joint production of artificial satellite systems. launch of Saudi satellites.

In 2018, trade exchange between Ukraine and the Kingdom of Saudi Arabia amounted to 935 million US dollars, as Ukrainian exports (grains such as wheat, barley, fats, oils of animal or vegetable origin, ferrous minerals and their products, meat and poultry) reached 749 million US dollars, and Saudi imports (plastics, polymers and compounds Organic chemicals, inorganic chemicals, and mineral fuels) \$ 186 million.

Promising areas for bilateral trade and economic cooperation are energy (renewable energy sources and their development), construction (infrastructure projects), water management and transportation (air, marine and urban), mechanical engineering and aircraft construction.

In September 2018 AD, the Saudi Agricultural Investment and Animal Production Company (SALIC) announced that one of its subsidiaries, UK Salik, had fully acquired the Maria Argo Holding Company, which is one of the largest agricultural companies in Ukraine.

The city of Kiev also hosted the expanded joint meeting of the Ukrainian-Saudi Business Council and the first Ukrainian-Saudi Forum for investment in the field of agriculture, within the framework of the sixth session of the Ukrainian-Saudi governmental committee for trade, economic, practical and technical cooperation held in November 2018 [1].

General authority of statics is pleased to provide its bulletin of trade exchange with the most important trade partners of (100) countries according, to the trade volume during the year 2016. Statistical tables are available to explain trade with 70 countries during the period from 2007-2016 by state groups. It explains total exports, imports and their percentages as compared to total KSA exports and/imports; in addition to the ranking of countries according to imports, exports and trade volume. Besides, graphs are provided to show data of exports and imports, plus key five commodities exported to or imported from each country in 2016 . The bulletin includes another table that summarizes trade exchange with 30 countries during 2015 and 2016, arranged according to the volume of trade recorded in 2016 [2].

The commercial relation between KSA and Ukraine. Ukraine is the second prominent country, of this group as it received $0.0001 \%$ of total KSA exports in 2016 The KSA exports to Ukraine amounted to SAR $127 \mathrm{~mm}$ It ranked 75 th among the countries importing from KSA. The key KSA exports to Ukraine were: Plastics and articles thereof, Inorganic chemicals, Misc. chemical products, Tannins; dyes and pigments, Machinery appliances; parts. The value of KSA imports from Ukraine in 2016 was SAR 2,723 mm, representing $1 \%$ of the total value of KSA imports. It ranked 36 th among the countries exporting to KSA. The key KSA imports from Ukraine were: Cereals, Iron and steel, Animal or vegetable fats and oils, Waste from the food; animal fodder, Articles of iron or steel, Consequently, the trade balance deficit turned to be SAR 2,596 $\mathrm{mm}$ in that year.

Relations between the Kingdom of Saudi Arabia and Ukraine Are the bilateral. The Kingdom of Saudi Arabia recognized the independence of Ukraine in 1992. And 
Table 2. Trade between Kingdom of Saudi Arabia and Ukraine

\begin{tabular}{|c|c|c|c|l|l|l|l|l|l|}
\hline & \multicolumn{2}{|c|}{$\begin{array}{c}\text { Volume of } \\
\text { trade }\end{array}$} & \multicolumn{3}{c|}{ Import } & \multicolumn{3}{c|}{ Export } & Year \\
\cline { 2 - 10 } & Rank & Value & $\%$ & Rank & Value & $\%$ & Rank & Value & \\
\hline$-2,754$ & 44 & 2,795 & $1 \%$ & 29 & 2,775 & $0 \%$ & 85 & 21 & 2007 \\
\hline$-5,200$ & 36 & 5,230 & $1 \%$ & 21 & 5,215 & $0 \%$ & 101 & 15 & 2008 \\
\hline$-2,637$ & 45 & 2,642 & $1 \%$ & 27 & 2,639 & $0 \%$ & 123 & 2 & 2009 \\
\hline$-3,791$ & 38 & 3,850 & $1 \%$ & 25 & 3,821 & $0 \%$ & 91 & 30 & 2010 \\
\hline$-4,216$ & 45 & 4,273 & $1 \%$ & 28 & 4,244 & $0 \%$ & 94 & 29 & 2011 \\
\hline$-5,641$ & 38 & 5,903 & $1 \%$ & 24 & 5,772 & $0 \%$ & 70 & 131 & 2012 \\
\hline$-2,952$ & 44 & 4,540 & $1 \%$ & 34 & 3,746 & $0 \%$ & 52 & 794 & 2013 \\
\hline$-4,452$ & 44 & 4,794 & $1 \%$ & 33 & 4,623 & $0 \%$ & 72 & 171 & 2014 \\
\hline$-3,418$ & 45 & 3,537 & $1 \%$ & 35 & 3,477 & $0 \%$ & 86 & 60 & 2015 \\
\hline$-2,596$ & 47 & 2,850 & $1 \%$ & 36 & 2,723 & $0 \%$ & 75 & 127 & 2016 \\
\hline
\end{tabular}

Table 3. TOP imported goods and exported goods in 2016

\begin{tabular}{|l|l|l|l|}
\hline VALUE & $\begin{array}{l}\text { TOP IMPORTED } \\
\text { COMMODITIES } \\
\mathbf{2 0 1 6}\end{array}$ & VALUE & $\begin{array}{l}\text { TOP EXPORTED } \\
\text { COMMODITIES } \\
\text { 2016 }\end{array}$ \\
\hline $\mathbf{1 4 4 2}$ & Cereals & 98 & $\begin{array}{l}\text { Plastic and articles } \\
\text { thereof }\end{array}$ \\
\hline $\mathbf{7 7 3}$ & Iron and steel & 24 & Inorganic chemical \\
\hline $\mathbf{1 9 4}$ & $\begin{array}{l}\text { Animal or vegetable } \\
\text { fats and oil }\end{array}$ & 1 & $\begin{array}{l}\text { Misc. chemical } \\
\text { products }\end{array}$ \\
\hline $\mathbf{1 0 7}$ & $\begin{array}{l}\text { Waste from the food } \\
\text { and animal fodder }\end{array}$ & 1 & $\begin{array}{l}\text { Tannins, dyes and } \\
\text { pigments }\end{array}$ \\
\hline $\mathbf{7 5}$ & $\begin{array}{l}\text { Articles of iron and } \\
\text { steel }\end{array}$ & 1 & $\begin{array}{l}\text { Machinery appliances } \\
\text { part }\end{array}$ \\
\hline
\end{tabular}

diplomatic relations between the two countries were established in April 1993. As there is a diplomatic representation of the Kingdom in Ukraine through its embassy in the Ukrainian capital, Kiev, and the Republic of Ukraine is represented by its embassy in Riyadh and the honorary consulate in Jeddah.

The economic and political relations between the two countries also witnessed cooperation in various fields, as in 2016 the Kingdom and Ukraine signed 7 agreements, including the double taxation agreement, the investment protection agreement, and the economic and commercial framework agreement for commercial, economic, scientific and technical cooperation (table 1).

Table 2 shows trade between Ukraine and Saudi Arabia. We see that imports outweigh exports.

Ukraine exports to Saudi Arabia was US\$749.02 Million during 2018, according to the United Nations COMTRADE database on international trade (table 3).

Saudi Arabia and Ukraine are discussing 17 fields of economic cooperation.

The Saudi Ministry of Environment, Water and Agriculture reviewed ways of joint cooperation with Ukraine in more than 17 diverse sectors, with the participation of 20 government agencies, during the preparatory meeting for the sixth session of the SaudiUkrainian joint committee, which will be held in the Ukrainian capital, from 12 to 23 November / Next November, at the Ministry's headquarters in Riyadh.

The clinic stated that the preparatory meeting reviewed more than 17 sectors for cooperation with the Ukrainian side, most notably in the fields of environment, water and agriculture, commercial, investment and financial fields, renewable energy, electricity, industry and aviation, transportation, science and space research, in addition to tourism, engineering, education and training. Existence of joint programs to facilitate communication between businessmen and review the available opportunity, through holding joint meetings, organizing activities and exchanging visits.

It is noteworthy that the volume of trade exchange between Saudi Arabia and Ukraine amounts to about $\$ 700$ million, and Ukraine enjoys multiple investment opportunities, and has achieved the highest indicator of GDP growth in Europe during the last ten years and macroeconomic indicators, as well as has great potential in the agricultural field, and is $56 \%$ of land. They are suitable for agricultural use.

3 commercial deals between Saudi and Ukrainian companies in the fields of energy, industry and real estate.

A number of Saudi and Ukrainian companies concluded contracts and commercial deals amounting to millions of riyals, during the joint Saudi-Ukrainian Business Council meeting, which held a conference at the headquarters of the Council of Saudi Chambers of Commerce and Industry. The meeting witnessed intense attendance by Ukrainian and Saudi businessmen from members of the Joint Business Council who have common commercial and investment relations, in addition to a number of business sectors and interested people who were invited to attend the meeting and who represent the various economic sectors in the two countries. And the three agreements that were signed between Saudi and Ukrainian businessmen: It is an agreement between Saudi Aramco and the Ukrainian Company for Industry and Energy, and an agreement between a Ukrainian company specialized in tourism and hotels with the Kingdom Wings Travel and Tourism Agency. Also, during the meeting, the Kyiv MiskBud Company was handed a certificate of registration of its work as the first company A Ukrainian company working in the real estate industry in the Kingdom and this 
Table 4. The list of current international agreement between Ukraine and the Kingdom of Saudi Arabia

\begin{tabular}{|c|c|c|}
\hline № & $\begin{array}{c}\text { Effective } \\
\text { date }\end{array}$ & Name of agreement \\
\hline 1 & 14.04 .1993 & $\begin{array}{l}\text { Protocol on the establishment of diplomatic relations between Ukraine and } \\
\text { the Kingdom of Saudi Arabia }\end{array}$ \\
\hline 2 & 29.12 .1996 & $\begin{array}{l}\text { Protocol between the State Committee of Migration of Ukraine and the } \\
\text { Ministry of Haj of the Kingdom of Saudi Arabia }\end{array}$ \\
\hline 3 & 19.06 .2003 & $\begin{array}{l}\text { Agreement on trade-economic, scientific, technical and investment } \\
\text { cooperation between Ukraine and the Kingdom of Saudi Arabia }\end{array}$ \\
\hline 4 & 24.05 .2005 & $\begin{array}{l}\text { Memorandum of Understanding between the Chamber of Commerce and } \\
\text { Industry of Ukraine and the Council of Chambers of Commerce and } \\
\text { Industry of the Kingdom of Saudi Arabia on establishment of the Ukrainian- } \\
\text { Saudi Business Council }\end{array}$ \\
\hline 5 & 18.02 .2009 & Agreement on reciprocal promotion and protection of investments \\
\hline 6 & 30.10 .2009 & $\begin{array}{l}\text { Memorandum of understanding on bilateral political consultations between } \\
\text { the Ministry of Foreign Affairs of Ukraine and the Ministry of Foreign } \\
\text { Affairs of the Kingdom of Saudi Arabia }\end{array}$ \\
\hline 7 & 09.10 .2011 & $\begin{array}{l}\text { Agreement on cooperation in the exploration and use of outer space for } \\
\text { peaceful purposes }\end{array}$ \\
\hline 8 & 01.12 .2012 & $\begin{array}{l}\text { Convention on avoidance of double taxation with respect to taxes on income } \\
\text { and estate and prevention of fiscal evasion. }\end{array}$ \\
\hline 9 & 01.11 .2017 & $\begin{array}{l}\text { Memorandum on investment cooperation in the field of agriculture between } \\
\text { the Cabinet of Ministers of Ukraine and the Government of the Kingdom of } \\
\text { Saudi Arabia. }\end{array}$ \\
\hline 10 & 01.11 .2017 & $\begin{array}{l}\text { Program of cooperation between Hennadiy Udovenko Diplomatic Academy } \\
\text { of Ukraine under the Ministry of Foreign Affairs of Ukraine and Prince } \\
\text { Saud Al-Faisal Institute for Diplomatic Studies under the Ministry of } \\
\text { Foreign Affairs of the Kingdom of Saudi Arabia. }\end{array}$ \\
\hline 11 & 01.11 .2017 & $\begin{array}{l}\text { Memorandum of understanding on cooperation and exchange of news } \\
\text { between the Ukrainian National Information Agency "Ukrinform" and the } \\
\text { Saudi Press Agency. }\end{array}$ \\
\hline 12 & 23.11 .2018 & $\begin{array}{l}\text { Memorandum of Understanding between the Government of Ukraine and } \\
\text { the Government of the Kingdom of Saudi Arabia on cooperation in the } \\
\text { sports sector }\end{array}$ \\
\hline 13 & 23.11 .2018 & $\begin{array}{l}\text { Memorandum of Cooperation between the National Bureau of Air } \\
\text { Accidents Investigation of Ukraine and the Aviation Investigation Bureau of } \\
\text { the Kingdom of Saudi Arabia }\end{array}$ \\
\hline 14 & 05.02 .2020 & $\begin{array}{l}\text { Agreement between the Cabinet of Ministers of Ukraine and the } \\
\text { Government of the Kingdom of Saudi Arabia on cooperation in the field of } \\
\text { defense }\end{array}$ \\
\hline
\end{tabular}

Kiev-based company is considered one of the largest Ukrainian contracting companies and has implemented nearly 42 million housing units and has projects in a number of countries of the world.

The Saudi-Ukrainian trade relations do not live up to the level of ambitions, as the volume of Saudi exports to Ukraine did not exceed 4 million dollars, while its imports from them amounted to 523 million dollars. Al-Rusais referred to the great developments in the Saudi economy, which he attributed to the package of economic policies and encouraging investment incentives, as the Saudi economy is classified among the 20 strongest global economies, and the Kingdom has also received international rankings in the attractiveness of its environment for foreign investment, adding that the next stage will witness a greater role for the Saudi business sector in Participating in the development process and expanding the production base, as it will witness a greater integration of the Kingdom's economy into the global economy through the movement of capital and the flow of goods, stressing their desire to build a strategic business partnership with Ukraine and attract Ukrainian investments to the Kingdom.

In addition to the Ukrainian side in the joint business council, the success achieved by the council in establishing cooperation establishing cooperation between Ukrainian and Saudi companies, such as what was done with Aramco, and working on establishing a Saudi-Ukrainian company working in the fields in addition to a cooperation agreement in the field of maritime transport with the Arab Company for Maritime Transport and a technical cooperation agreement Which could put it in working status in Saudi Arabia (table 4).

Investment and tourism, including holding negotiations Virtualization between the members of the Makkah Chamber and representatives of the leading Ukrainian tourism companies in the month of October [4].

The Ukrainian Iron \& Steel in Figures 2020 report confirm the increase in exports of metal sheets and rolled pipes to Indonesia, Saudi Arabia, Thailand and the UAE, pointing out that the Middle East region North Africa remains the main export trend of Ukrainian sheet metal products, which account for $35 \%$ of exports of these products. He pointed out that Russia is the largest market for the export of metal sheets at $16.5 \%$, followed by Turkey, which imports $10 \%$ of these sheets. It is worth noting that the UAE and Saudi Arabia are among the largest importers of poultry and eggs from Ukraine during the first half of this year [6].

Ukraine reduced exports of poultry meat by $27 \%$ during the first half of this year 2020 compared to the same period last year 2019, according to the Ukrainian Customs 
Authority. The authority revealed in a press release published on Friday, June 12, that the largest importers of poultry from Ukraine in the aforementioned period were the Netherlands (18\%), the Kingdom of Saudi Arabia $(15 \%)$, and the United Arab Emirates (13\%). She added that Ukraine also reduced egg exports in the aforementioned period by $12 \%$, compared to the same period last year.

It stated that the UAE was the largest importer of eggs from Ukraine, at $28.5 \%$, followed by Saudi Arabia (22\%), and Latvia (10\%).

TheSaudi "Sago" company specialized in agricultural affairs bought more than 60 thousand tons of Ukrainian wheat at a price of $\$ 248$ per ton from the investment company, "Salik", which previously owned the "Maria" agricultural enterprise in Ukraine. In news of Ukraine and the UAE, Ukrainian Foreign Minister Dmytro Kuliba said that the UAE is one of the most attractive countries for Ukrainian exports [7].

Ukraine increased exports of various meat by almost $11 \%$ in the first 9 months of the current year 2019 compared to the same period last year 2018, according to the Ukrainian Agricultural Economics Institute. The institute revealed in a statement issued today, Thursday, November 7, that meat exports increased from 479 million dollars to 531 million dollars in the mentioned period.

The institute stated that the Kingdom of Saudi Arabia was the largest importer of Ukrainian meat with $18.1 \%$ of the total mentioned exports, with a value of 96 million dollars, which is almost three times more than the total Saudi revenues from Ukrainian meat for the same period last year (31 million dollars).

The Netherlands came second from the list of the largest Ukrainian meat importers, with $15.2 \%$, followed by Slovakia ( $8.9 \%)$.

It should also be noted that there are two other Arab countries that occupied advanced positions in this list, which are Iraq (4.4\%) and the United Arab Emirates $(3.8 \%)$. It was announced late last month that Saudi Agricultural and Livestock Investment Co, SALIC, is planning to implement a number of projects in the Black Sea Basin, southern Ukraine, including the purchase of a wheat plant [8].

Vadim Fakher and Shev, Ukraine's ambassador to Saudi Arabia, "There are Saudi investment companies with long experience that have strongly and positively entered the Ukrainian agricultural market, to rent agricultural lands with large areas in the western regions to grow wheat, barley, corn, soybeans, sugar beets, potatoes and tomatoes." "The Ukrainian authorities are working to simplify visa procedures between the two countries, and we are working to take care of Saudi investors by developing a new system for logistical support for their activities in our country," he added.

He stressed that the recent signing of a memorandum of understanding between the governments of Ukraine and Saudi Arabia in Riyadh aims at investment cooperation in the agricultural field to provide the legal basis for the practice of activities in one of the most priority areas of bilateral cooperation.
He pointed out that based on the memorandum, the two parties will encourage the development of cooperation to attract investments in the agricultural field, including livestock and fisheries, and support investors and implement projects by providing appropriate consultations and holding trade and investment exhibitions in the agricultural field, including livestock and fish.

"The memorandum will help exchange more information on investment strategies and systems, the investment environment and their potentials in the agricultural field, including the livestock and fisheries sectors, and the services granted to foreign investors in Ukraine," added Fakhrooshev.

He explained that Ukraine considers Saudi Arabia one of its most important trade and economic partners in the Arab Gulf region and the Middle East in general, and "ranks second among Arab countries in terms of the volume of trade exchange."

He stressed that the volume of trade and service exchange between the two countries amounts to one billion US dollars annually, explaining that the two parties should put in place additional mechanisms to ensure more sustainability and methodology in bilateral economic cooperation and to expand and diversify export and import operations, in addition to agricultural products: wheat, barley, corn, soybeans, sugar beets, potatoes and tomatoes. Like ferrous metals and their products.

The Ukrainian ambassador in Riyadh indicated that Saudi Arabia imports grains in large quantities, as it is one of the largest importers of fodder barley used in the livestock sector in the world.

He stated that the Kingdom's government takes into account the issue of global food security and the growth in world food prices, as it pays great attention to forming a national strategic reserve and stimulating foreign purchases.

He pointed out that at present, there are two forms of Ukrainian-Saudi cooperation in the agricultural sector: direct trade "as is often the case" and investment in the Ukrainian agricultural sector by renting lands and establishing a suitable productive infrastructure on them to export manufactured products to Saudi Arabia.

It is noteworthy that Ukraine, according to the estimates of international specialists, is one of the few countries able to increase the volume of agricultural production by three times at the expense of investments in its agricultural sector, and about 30 percent of the world's reserves of fertile black soil are in Ukraine.

Ambassador Fakherushev stated that during the years 2015-2016, Ukrainian agricultural products exports to Saudi Arabia accounted for about two-thirds of all export operations, among them, in the first place, grains, particularly barley, fats and oils of animal or vegetable origin, milk, dairy products, meat, eggs and natural honey.

He pointed out that Ukraine is ready to increase its exports to the Kingdom of animal products, "including dairy products, lamb, beef and chicken", and food 
industries, "flour products, sweets, oils and fats products" and organic products.

He explained that there is positive experience in entering Saudi companies in the Ukrainian agricultural market. For example, the United Farmers Holding Company leased large agricultural lands in the western regions of Ukraine to grow wheat, barley, corn, soybeans, sugar beets, potatoes and tomatoes.

"We are witnessing the interest of Saudi investors in developing a new logistical support system for their activities in our country, and Ukraine is interested in the participation of Saudi investors, whether from the private or government sector, in implementing attractive projects in our country, as we are open to offering them investment opportunities in the fields of energy, infrastructure, aircraft engineering, heavy engineering and industries, "he said. Defense, agriculture and shipbuilding, therefore, we invite them to participate in the privatization of state-owned enterprises in Ukraine" [9].

\section{CONCLUSION}

Saudi-Ukrainian cooperation in the field of education is considered a priority for both countries. A humanitarian program to assist Saudi Arabian students in Ukrainian universities has been launched. A special role is played by the signing of the Protocol between the State Committee for National Migration of Ukraine and the Ministry of Hajj KSA on the pilgrimage of Muslims of Ukraine to Islamic shrines located in the Kingdom.

The importance of the Persian Gulf region for Ukraine is due to the significant potential for mutually beneficial trade and economic cooperation. Despite the fact that Ukraine is one of the energy-deficient countries, the possibilities of import or transit of energy from the Gulf states are quite limited. The priorities of Ukraine's policy in the region are the development of balanced, equal and mutually beneficial relations, strengthening Ukraine's economic position in the region's markets, maintaining security at the southern borders of our state, strengthening regional security and stability.

Economic profitability of Ukraine's cooperation and Saudi Arabia is beyond doubt. The Kingdom of Saudi Arabia is huge market for many Ukrainian goods, for large-scale scientific and technical cooperation with Ukraine, which in turn provides profitable agreements and orders, creation of new workers places in our country. Investment opportunities Kingdoms are really significant, so their involvement to Ukraine should become one of the key issues relationship between the two parties.

Ukraine, in turn, has competitive advantages and favorable opportunities for exports their goods to the Kingdom. In particular, ours the country can offer cheaper, but also a quality alternative to Western goods and services. This is especially true of the products of the domestic agricultural sector and the aircraft industry. In general, there are significant reserves for the future intensification of trade and economic cooperation between the two countries.

\section{References:}

1. Embassy of Ukraine in the Kingdom of Saudi Arabia (2012), "Trade and economic cooperation between Ukraine and the Kingdom of Saudi Arabia", available at: https:// saudiarabia.mfa.gov.ua/ar/partnership/532-torgovelynojekonomichne-spivrobitnictvo-mizh-ukrajinoju-tasaudivsykoju-aravijeju (Accessed 15 Sept 2020).

2. General authority for statics (2016), "Trade exchange between the kingdom and major partners", available at: general authority for statics/Bulletins /2016/ page 3 (Accessed 15 Sept 2020).

3. Interfax (2020), "Ukraine, Saudi Arabia discuss mutual trade, investment development", available at: https: / /en.interfax.com.ua/news/investments / 680148.html (Accessed 15 Sept 2020).

4. Ukrainian-Arabic website (2020), "Prospects for cooperation between Saudi Arabia and Ukraine", available at: http://arab.com.ua/ar/sfyr-aaqkraanyaa-Ideaalsiqdyh-ybth-faaq-aaltiaaqn-mi-aalghrfh-aaltjaaryhaalnaaiyh-bmkh-aalmkrmh (Accessed 15 Sept 2020).

5. Embassy of Ukraine in the Kingdom of Saudi Arabia (2012), "Bilateral agreements between Ukraine and the Kingdom of Saudi Arabia", available at: https:// saudiarabia.mfa.gov.ua/en/partnership/530-dogovirnopravova-baza-mizh-ukrajinoju-ta-saudivsykoju-aravijeju (Accessed 15 Sept 2020).

6. Ukrainian-Arabic website (2020), "Ukraine increases its exports of minerals to Saudi Arabia", available at: http://arab.com.ua/ar/aaqkraanyaa-tzydaadrthaa-mn-aalmiaadn-aale-aalsiqdyh-qaalaamaaraat (Accessed 15 Sept 2020).

7. Ukrainian-Arabic website (2020), "Saudi Arabia is one of the largest importers of poultry and eggs from Ukraine within half a year", available at: http:// arab.com.ua/ar/aalaamaaraat-qaalsiqdyh-mn-aakbraaldql-aalmstqrdh-lldqaajn-qaalby-mn-aaqkraanyaa-khlaalnf-iaam (Accessed 15 Sept 2020).

8. Ukrainian-Arabic website (2019), "Saudi Arabia is the largest importer of meat from Ukraine since the beginning of the year", available at: http://arab.com.ua/ ar / mihd-aalaaqtaad-aalzraaiy-aalsiqdyh-aakbraalmstqrdyn-Ilqm-mn-aaqkraanyaa-mndh-mli-aaliaam (Accessed 15 Sept 2020).

9. www.aleqt.com (2017), "Saudi companies rent lands in Ukraine to grow wheat", available at: https:// www.aleqt.com/2017/11/13/article_1282531.html (Accessed 15 Sept 2020).

10. www.aleqt.com (2009), "3 commercial deals between Saudi and Ukrainian companies in the fields of energy, industry and real estate", available at: https:// www.aleqt.com /2009/05/01/article_136402.html (Accessed 15 Sept 2020).

11. al-ain.com (2018), "Saudi Arabia and Ukraine are discussing 17 fields of economic cooperation", available at: https://al-ain.com/amp/article/saudi-arabiaukraine-discuss-economic-cooperation (Accessed 15 Sept 2020).

12. Aulin, O. (2020), "UAE - "old" "new" player in the Middle East", Ukraine: events, facts, comments, vol. 12, pp. 37-43, available at: http://nbuviap.gov.ua/images/ ukraine/2020/ukr12.pdf (Accessed 15 Sept 2020). Стаття надійшла до редакиї 19.09.2020 p. 